\title{
High proportion of hepatitis $C$ virus genotypes 1 and 3 in a large cohort of patients from Southern Brazil
}

\author{
Cláudia Maria Dornelles da Silva/*/+, Cintia Costi/****, Luciano Percival Krug**, \\ Ana Beatris Ramos***, Tarciana Grandi/****, Vitório Luiz Gandolfi*****, \\ Maria Elizabeth Menezes $* * * * * *$, Maristela Ocampos $* * * * * * * / * * * * * * * *$, \\ Christian Niel********, Maria Lucia Rosa Rossetti/*
}

\begin{abstract}
Centro de Desenvolvimento Científico e Tecnológico do Estado do Rio Grande do Sul, Fundação Estadual de Produção e Pesquisa em Saúde, Secretaria de Saúde do Estado do Rio Grande do Sul, Av. Ipiranga, 5400, 90610-000 Porto Alegre, RS, Brasil

*Universidade Luterana do Brasil, Canoas, RS, Brasil **Laboratório Amplicon, Porto Alegre, RS, Brasil ***Fundação de Cardiologia, Alvorada, RS, Brasil ****Centro de Biotecnologia, Universidade Federal do Rio Grande do Sul, Porto Alegre, RS, Brasil *****Setor de Virologia, Laboratório Central de Santa Catarina, Secretaria Estadual de Saúde do Estado de Santa Catarina, Florianópolis, SC, Brasil ******Laboratório DNAnalise, Florianópolis, SC, Brasil *******Instituto de Biotecnologia Aplicada, Florianópolis, SC, Brasil ********Laboratório de Virologia Molecular, Instituto Oswaldo Cruz-Fiocruz, Rio de Janeiro, RJ, Brasil
\end{abstract}

Hepatitis $C$ virus (HCV) isolates have been divided into six genotypes (1 to 6). The duration of hepatitis $C$ standard treatment is 48 weeks for patients infected with HCV genotype 1 vs 24 weeks for those infected with genotypes 2 and 3. A total of 1544 HCV isolates from chronic patients living in the southern Brazilian states of Rio Grande do Sul (RS, $n=627)$ and Santa Catarina $(S C, n=917)$ were genotyped by restriction fragment length polymorphism (RFLP) of polymerase chain reaction (PCR) products. In RS, 338 (53.9\%; 95\% CI 50.0 $57.8 \%), 34$ (5.4\%; 95\% CI $3.8-7.4 \%)$ and, 255 (40.7\%; 95\% CI 36.9 - 44.6\%) samples were from genotypes 1, 2, and 3, respectively. In SC, 468 (51\%; 95\% CI 47.8 - 54.2\%), 26 (2.9\%; 95\% CI $1.9-4.1 \%)$ and, 423 (46.1\%; $95 \%$ CI 42.9 - 49.3\%) samples were from genotypes 1, 2, and 3, respectively. Genotyping results were confirmed by direct nucleotide sequencing of PCR products derived from 68 samples, without any discrepancy between PCR-RFLP and nucleotide sequencing methods. In conclusion, almost half of the hepatitis $C$ patients from South of Brazil are infected by genotypes 2 and 3 and, these results have important consequential therapeutic implications as they can be treated for only 24 weeks, not 48.

Key words: hepatitis C virus genotypes - polymerase chain reaction - restriction fragment lengh polymorphism nucleotide sequencing - Rio Grande do Sul - Santa Catarina

Chronic hepatitis $\mathrm{C}$, caused by infection with hepatitis $\mathrm{C}$ virus $(\mathrm{HCV})$, is a global health problem, with more than 170 million infected individuals worldwide (WHO 1999). In $15-20 \%$ of acute HCV infections, the patients recover spontaneously. However, in a large majority of cases, the disease runs a chronic course, clinically silent. Persistent infection may lead to severe liver diseases, such as cirrhosis and hepatocellular carcinoma, which require intensive treatment regimens and, in some cases, liver transplantation, and long-term care.

$\mathrm{HCV}$ is primarily transmitted by the parenteral route. Sexual and perinatal transmissions have also been demonstrated, although less frequent (Poupon 2005). Since there is no available vaccine against hepatitis C, the only means to lower the disease burden are prevention of new infections and treatment of chronic carriers.

$\mathrm{HCV}$ has a large genetic heterogeneity. Virus isolates have been classified into six genotypes (1 to 6), based

Financial support: Fapergs (503710; 04/14956), Padct-Fepps (01/ 2001, 02/2002)

+Corresponding author: cmdornelles@terra.com.br

Received 11 June 2007

Accepted 5 October 2007 on nucleotide sequence divergence of $30-35 \%$ (Simmonds 2004). Genotypes 1, 2, and 3 circulate around the world, while genotypes 4,5 , and 6 are restricted to determined geographical areas (McOmish et al. 1994). In Brazil, genotypes 1, 2, and 3 predominate, although genotypes 4 and 5 have also been found (Campiotto et al. 2005).

$\mathrm{HCV}$ genotype determination is necessary to define the optimal duration of therapy and the likelihood of response. According to the European Association for the Study of the Liver (EASL 1999) International Consensus Panel and National Institutes of Health (NIH 2002) Consensus Panel on management of hepatitis $\mathrm{C}$, standard therapy for chronic HCV infection is based on combination of pegylated interferon (PEG IFN) alfa-2a or alfa-2b with ribavirin (RBV) during 48 weeks for patients infected with genotype 1 or 4 , or IFN alfa-2a or alfa-2b with RBV during 24 weeks for those infected with genotypes 2 or 3 .

Most genotyping methods include a first step of reverse transcription of viral RNA and polymerase chain reaction (PCR) amplification. The conserved 5' noncoding region (NCR) of the $\mathrm{HCV}$ genome has been used as a target for a number of diagnostic assays. This region can be characterized by probe hybridization or by variations in restriction pattern. HCV genotype can also be determined indirectly by using type-specific antibodies in a competitive enzyme immunoassay (Forns \& Costa 2006). 
In Brazil, several studies have been conducted to determine the distribution of HCV genotypes among different groups of individuals. Most of these studies have shown a predominance of genotype 1 (Krug et al. 1996, Oliveira et al. 1999, Paraná et al. 2000, Busek \& Oliveira 2002, Codes et al. 2003, Vogler et al. 2004, Martins et al. 2006, Silva et al. 2006). The aim of the present study was to determine with precision the frequency of each HCV genotype in the South of Brazil, by studying a large cohort of patients from Rio Grande do Sul (RS) and Santa Catarina (SC), the southernmost states of the country.

\section{PATIENTS, MATERIALS AND METHODS}

Blood samples - Blood samples were collected between 2001 to 2003 from 627 chronic hepatitis C patients living in different counties of the state of RS. The samples were selected from HCV RNA positive patients attending ambulatories of state Public Health Service. Genotyping was required to define treatment management and for free supply of antiviral drugs. Demographic data (age and gender) were collected retrospectively from patient medical records. This project was approved by the Ethical Committee of the Fundação Estadual de Produção e Pesquisa em Saúde.

Samples were collected in tubes containing EDTA, centrifuged at the collect site (Public Health Central Laboratory, Porto Alegre, RS), and sent immediately in a refrigerated container to the Amplicon Laboratory, Porto Alegre, for HCV genotyping. All samples were stored at $-70^{\circ} \mathrm{C}$ until use. To avoid RNA degradation, aliquots were not thawed more than once prior to analysis.

In addition, blood samples of 917 chronic hepatitis $\mathrm{C}$ patients from different counties of the state of SC were collected between 2003 to 2006 at, or sent to, DNAnalise laboratory, Florianópolis, SC, for $\mathrm{HCV}$ genotyping. Gender data from 181 patients were collected retrospectively from laboratory records.

Viral RNA extraction, $c D N A$ synthesis and PCR amplification - Viral RNA was extracted from $100 \mathrm{ml}$ of plasma using the guanidinium isothiocyanate-phenolchloroform method (Chomcynski \& Sacchi 1987). Reagents for RNA extraction, cDNA synthesis, and PCR were obtained from Invitrogen (Carlsbad, CA). Each batch of samples was processed with positive and negative controls in all steps. After extraction, the pellets were resuspended in a volume of $10 \mathrm{ml}$ containing $10 \mathrm{mM}$ Tris $\mathrm{HCl}, \mathrm{pH} 8.0$, and $10 \mathrm{U}$ of Rnasin. Reverse transcription was carried out with $20 \mathrm{U}$ of Moloney murine leukemia virus reverse transcriptase and $0.5 \mu \mathrm{M}$ of antisense primer 5'-CATGGTGCACGGTCTACGAGACC-3' (nt 310332 ) in $50 \mathrm{mM}$ Tris- $\mathrm{HCl}, \mathrm{pH} 8.3,75 \mathrm{mM} \mathrm{KCl}, 3 \mathrm{mM}$ $\mathrm{MgCl}_{2}$, and $0.5 \mathrm{mM}$ each deoxynucleotide for $1 \mathrm{~h}$ at $37^{\circ} \mathrm{C}$.

PCR assays (for amplification of the 5' NCR of the $\mathrm{HCV}$ genome) were carried out in a final volume of 50 il containing $5 \mu \mathrm{l}$ of the cDNA reaction mix, 5 units of Taq DNA polymerase, $20 \mathrm{mM}$ Tris-HCl, $\mathrm{pH} 8.4,50 \mathrm{mM}$ $\mathrm{KCl}, 0.2 \mathrm{mM}$ of each deoxynucleotide and $0.5 \mu \mathrm{M}$ of each primer. First round was performed with external sense primer 5'-GGCGACACTCCACCATAGATC-3' (nt 6 - 26) and the external antisense primer described above.
Ten $\mu l$ of the first round product, along with internal sense 5'-GGAACTACTGTCTTCACGCAGA-3' (nt 39 - 56) and antisense 5'-TCGCAAGCACCCTATCAGGCAG-3' (nt 277 - 298) primers, were used in the second round. Both reactions were for 35 cycles at $94^{\circ} \mathrm{C}$ for $30 \mathrm{~s}, 50^{\circ} \mathrm{C}$ for $30 \mathrm{~s}$ and $72^{\circ} \mathrm{C}$ for $60 \mathrm{~s}$, with a final extension step of $72^{\circ} \mathrm{C}$ for $7 \mathrm{~min}$ (Krug et al. 1996). PCR products were separated by $2 \%$ agarose gel electrophoresis and visualized under UV light after ethidium bromide staining.

Genotyping - HCV genotyping was performed by PCR-RFLP, according to the method described by McOmish et al. (1994). The genotypes of $68 \mathrm{HCV}$ samples were confirmed by direct nucleotide sequencing of the 5' NCR region of HCV. Nested PCR products (259 bp) were submitted to cycle sequencing reactions, using the ABI Prism BigDye Terminator Cycle Sequencing Ready Reaction kit (Applied Biosystems, Foster City, CA). The reaction mixture contained 8 il of Terminator Ready Reaction Mix, 8 il of water, 1 pmol of PCR internal primer and 2 il of PCR products. Sequencing reactions were performed in a PTC-200 thermocycler (MJ Research, Watertown, MA) under the following conditions: 25 cycles at $96^{\circ} \mathrm{C}$ for $10 \mathrm{~s}, 50^{\circ} \mathrm{C}$ for $5 \mathrm{~s}$, and, $60^{\circ} \mathrm{C}$ for $4 \mathrm{~min}$. Reaction products were analyzed in an Automated DNA Sequencer ABI3100 (Applied Biosystems). Both DNA strands were sequenced.

The results were edited and analyzed with nucleotidenucleotide BLAST (blastn) software and the genotypes were determinated by comparing the reference sequences deposited in the DNA databanks. Also, the overall sequences were confirmed by phylogenetic analysis using the PAUP program (version 4.0), using the sequences of 5' NCR region downloaded from Los Alamos National Laboratory (www.hcv.lanl.gov). The nucleotide sequences determined in this work were deposited in the GenBank database under the accession numbers EF558854EF558890 (genotype 1), EF564603-EF564609 (genotype 2), and EF571224-EF571247 (genotype 3).

Statistical analysis - Fisher's exact test and chisquare test with Yates' correction were used to analyze qualitative data. All $p$ values are two-tailed; $p$ values $<$ 0.05 were considered statistically significant. The statistical analysis included the calculation of the $95 \%$ confidence interval $(95 \% \mathrm{CI})$.

\section{RESULTS}

The mean age of the 627 chronic hepatitis $C$ patients living in the state of RS was 46 years old (range 18 to 75 years). Three hundred fifty subjects $(55.8 \%)$ were male and $277(44.2 \%)$ were female. The Table shows that genotypes 1,2 , and 3 were detected, with a predominance of genotypes $1(53.9 \%)$ and $3(40.7 \%)$, and a low proportion $(5.4 \%)$ of genotype 2 . No significant correlation of $\mathrm{HCV}$ genotypes with age or gender was found.

The prevalence of HCV genotypes in SC was studied in a total of 917 patients. Among 181 patients whose gender was known, $129(71.3 \%)$ subjects were male and $52(28.7 \%)$ were female. Genotype 1 was also predominant $(51 \%)$, followed by genotypes $3(46.1 \%)$, and 2 $(2.9 \%)$ (Table). 
TABLE

Distribution of Hepatitis C virus genotypes in the state of Rio Grande do Sul and Santa Catarina, Brazil, 2001-2006

\begin{tabular}{lrcc}
\hline State/ Genotype & $\mathrm{N}$ & Frequency $(\%)$ & $95 \% \mathrm{CI}(\%)$ \\
\hline Rio Grande do Sul & & & \\
1 & 338 & 53.9 & $50.0-57.8$ \\
2 & 34 & 5.4 & $3.8-7.4$ \\
3 & 255 & 40.7 & $36.9-44.6$ \\
4 & 0 & 0 & $0-0.5$ \\
5 & 0 & 0 & $0-0.5$ \\
6 & 0 & 0 & $0-0.5$ \\
\hline Total & 627 & 100 & - \\
\hline Santa Catarina & & & \\
1 & 468 & 51.0 & $47.8-54.2$ \\
2 & 26 & 2.9 & $1.9-4.1$ \\
3 & 423 & 46.1 & $42.9-49.3$ \\
4 & 0 & 0 & $0-0.4$ \\
5 & 0 & 0 & $0-0.4$ \\
6 & 0 & 0 & $0-0.4$ \\
\hline Total & 917 & 100 & - \\
\hline
\end{tabular}

PCR-RFLP genotyping results of 68 samples (37 were from genotype 1 , seven from genotype 2 , and 24 from genotype 3 ) were confirmed by direct nucleotide sequencing of PCR products. No discrepancy was found between the two methods.

\section{DISCUSSION}

Hepatitis $\mathrm{C}$ infection may lead to a substantial health and economic burden over the next 10 to 20 years (Wong 2006). From a public health perspective, the implementation of molecular tests as an integral part of the diagnostic and therapeutic management of infections with HCV should be imperative.

Due to the different treatment schedules between genotype 1 ( 48 weeks) vs genotypes 2 and 3 ( 24 weeks), genotype distribution has significant influence on the total costs and morbidity of $\mathrm{HCV}$ treatment. The gold standard methodology for genotyping HCV samples is represented by nucleotide sequencing (Simmonds 1995). However, in a routine diagnostic virology laboratory, simpler, faster and less expensive methods are required. Here we compare RFLP-PCR, an indirect method used to type all samples, and nucleotide sequencing analysis, in order to evaluate the validity of RFLP-PCR in the population under study. All the 68 samples tested gave the same genotyping result with both methods, with a $100 \%$ accordance rate between them.

In a previous study performed in 1995 - 1996 in RS, and including $100 \mathrm{HCV}$ RNA positive patients (Krug et al. 1996), genotypes 1,2 , and 3 were found at frequencies of $55 \%, 8 \%$, and $37 \%$, respectively. Here, the HCV genotype distribution was determined in a population of more than 1500 patients living in the RS and SC, South of Brazil. This represented the largest study in this region of the world. Our data show that genotypes 1
$(53.9 \%), 2(5.4 \%)$, and $3(40.7 \%)$ are the only ones circulating in the South of Brazil, with frequencies similar to those previously found, indicating the absence of substantial changes during the last decade.

The high frequency of genotype 3 observed in RS and $\mathrm{SC}$ is a relevant finding because the response to alpha interferon is generally better for this genotype than for the others, consequently reducing the antiviral treatment duration and the costs (Wong 2006, Van Soest et al. 2006). Finally, our data can provide new insights to facilitate surveillance policies with the recognition of the need for local resources to face this frequently silent infection.

\section{ACKNOWLEDGEMENTS}

To Dr Arnaldo Zaha for his helpful comments of the manuscript and Secretaria Estadual de Saúde do Rio Grande do Sul.

\section{REFERENCES}

Busek S, Oliveira G 2002. Hepatitis C and hepatitis B virus infection in different hemodialysis units in Belo Horizonte, Minas Gerais, Brazil. Mem Inst Oswaldo Cruz 97: 775-778.

Campiotto S, Pinho JRR, Carrilho FJ, da Silva LC, Souto FJD, Spinelli V, Pereira LMMB, Coelho HSM, Silva AO, Fonseca JC, Rosa H, Lacet CMC, Bernardini AP 2005. Geographic distribution of hepatitis $\mathrm{C}$ virus genotypes in Brazil. Braz $J$ Med Biol Res 38: 41-48.

Chomcynski P, Sacchi N 1987. Single-step method of RNA isolation by acid guanidinium thiocyanate-phenol-chloroform extraction. Anal Biochem 162: 156-159.

Codes K, de Freitas LAR, Santos-Jesus R, Vitvitski L, Silva LK, Trepo C, Reis MG, Paraná R 2003. Comparative study of hepatitis $\mathrm{C}$ virus genotypes 1 and 3 in Salvador, Bahia. Braz J Infect Dis 7: 409-417.

EASL- European Association for the Study of the Liver, International Consensus Conference on Hepatitis C 1999. J Hepatol 31 (Suppl. I): 3-8.

Forns X, Costa J 2006. HCV virological assessment. J Hepatol 44: $\mathrm{S} 35-39$.

Krug LP, Lunge VR, Ikuta N, Fonseca ASK, Cheinquer H, Ozaki LS, Barros SGS 1996. Hepatitis C virus genotypes in Southern Brazil. Braz J Med Biol Res 29: 1629-1632.

Martins RMB, Teles SA, Freitas NR, Motta-Castro RC, Souto FJD, Mussi A, Amorim RMS, Martins CRF 2006. Distribution of hepatitis $\mathrm{C}$ virus genotypes among blood donors from mid-west region of Brazil. Rev Inst Med Trop São Paulo 48: 53-55.

McOmish F, Yap PL, Dow BC, Follett EAC, Seed C, Keller AJ, Cobain TJ, Krusius T, Kolho E, Naukkarinen R, Lin C, Lai C, Leong S, Medgyesi GA, Héjjas M, Kiyokawa H, Fukada K, Cuypers T, Saeed AA, Al-Rasheed AM, Lin M, Simmonds P 1994. Geographical distribution of Hepatitis C virus genotypes in blood donors: an International collaborative survey. J Clin Microbiol 32: 884-892.

NIH - National Institute of Health, Consensus Development Conference Statement: management of hepatitis C 2002. Hepatology 36 (Suppl. I): S3-20.

Oliveira MLA, Bastos FI, Sabino RR, Paetzold U, Schreier E, Pauli G, Yoshida CFT 1999. Distribution of HCV genotypes among different exposure categories in Brazil. Braz J Med Biol Res 32: 279-282. 
Paraná R, Vitvitski L, Berby F, Portugal M, Cotrim HP, Cavalcante A, Lyra L, Trepo C 2000. HCV infection in northeastern Brazil: unexpected high prevalence of genotype $3 \mathrm{a}$ and $\mathrm{ab}-$ sence of African genotypes. Arq Gastroenterol 37: 213-216.

Poupon R 2005. Hepatitis C: epidemiology, management and treatment. Bull Acad Natl Med 189: 375-384.

Silva LK, Silva MBS, Rodart IF, Lopes GB, Costa FQ, Melo ME, Gusmão E, Reis, MG 2006. Prevalence of hepatitis C virus (HCV) infection and HCV genotypes of hemodialysis patients in Salvador, Northeastern Brazil. Braz J Med Biol Res 39: 595-602.

Simmonds P 1995. Variability of hepatitis C virus. Hepatology 21: 570-583.

Simmonds P 2004. Genetic diversity and evolution of hepatitis C virus - 15 years on. J Gen Virol 85: 3173-3188 van Soest H, Boland GJ, Erpecum KJ 2006. Hepatitis C: changing genotype distribution with important implications for patient management. Neth J Med 64: 96-98.

Vogler IH, Nishiya A, Morimoto HK, Reiche EM, Bortoliero AL, Matsuo T, Sabino EC, Vaz AJ 2004. Serological, epidemiological and molecular aspects of hepatitis $C$ virus infection in a population from Londrina, PR, Brazil, 2001-2002. Rev Inst Med Trop São Paulo 46: 303-308.

WHO-World Health Organization 1999. Global surveillance and control of hepatitis C. Report of a WHO Consultation organized in collaboration with the Viral Hepatitis Prevention Board, Antwerp, Belgium. J Viral Hep 6: 35-47.

Wong JB 2006. Hepatitis C: cost of illness and considerations for the economic evaluation of antiviral therapies. Pharmacoeconomics 24: 661-672 